\title{
Improving the Quality of Tofu Liquid waste by the Sedimentation Process and the Phytoremediation of Water Hyacinth (Eichornia crassipes)
}

\author{
Herlina Fitrihidajati ${ }^{1}$, Fida Rachmadiarti ${ }^{2}$, Dwi Savitri Vidyawati ${ }^{3}$ \\ Department of Biology \\ Universitas Negeri Surabaya \\ Surabaya, Indonesia \\ 1'herlinafitrihidajati@unesa.ac.id, ${ }^{2}$ fidarachmadiarti@unesa.ac.id, ${ }^{3}$ dwisavitri@mhs.unesa.ac.id
}

\begin{abstract}
Waste from the tofu industry produced the pollutant like $\mathrm{NH}_{3}, \mathrm{NO}_{2}, \mathrm{NO}_{3}$ with high content that caused environmental pollution. Hence, the processing of tofu liquid waste was needed. The purpose of this research was to determine the effect on the levels of $\mathrm{pH}, \mathrm{NH}_{3}, \mathrm{NO}_{2}, \mathrm{NO}_{3}$ and to determine the biomass of water hyacinth. This research was an experimental research with three research namely tofu liquid waste $100 \%$ (control), sedimentation process and the phytoremediation of water hyacinth with 9 duplicates. Parameters measured include $\mathbf{p H}$, $\mathrm{NH}_{3}, \mathrm{NO}_{2}, \mathrm{NO}_{3}$, and biomass. The Data were analyzed using the one-way ANAVA then continued with Duncan Test at 5\% level and analogous to the quality standard of East Java Governor Decree Number 45 of 2002 . The results showed that the phytoremediation of water hyacinth by sedimentation was able to increase $\mathrm{pH}$ levels from 4.21 to 7.37 ; reduce $\mathrm{NH}_{3}$ levels from 6.41 to 1.83 ; decrease NO2 levels from 1.94 to 0.61 ; decrease NO3 levels from 15.91 to 12.66; and increase the biomass of water hyacinth. The Phytoremediation of water hyacinth (Eichornia crassipes) by sedimentation can be used to improve the quality of liquid waste in accordance to the standard of quality for the parameters of $\mathrm{pH}, \mathrm{NO}_{2}$ and $\mathrm{NO}_{3}, \mathrm{NH}_{3}$.
\end{abstract} $\mathrm{NO}_{3}$

Keywords - tofu liquid waste, water hyacinth, $p \mathrm{H}, \mathrm{NH}_{3}, \mathrm{NO}_{2}$,

\section{INTRODUCTION}

The tofu factory is a food industry that was widely available in Indonesia. Waste from the tofu industry produced very high pollutants and caused in environmental pollution [1]. The tofu liquid waste containing N-total was quite high, the content reached $93,700 \mathrm{mg} / 1$ [2]. The concentration of ammonia $\left(\mathrm{NH}_{3}\right)$ and nitrate $\left(\mathrm{NO}_{3}\right)$ in tofu liquid waste was $27.99 \mathrm{mg} / \mathrm{L}$ and $65.89 \mathrm{mg} / \mathrm{L}$, it was known that the content had been exceeding the waste quality standards [3]. Tofu liquid waste was turbid and acidic. The turbidity was caused by inorganic and organic substances which were dissolved and suspended. If the suspended content was high, the water would become more turbid. Besides turbid, tofu waste also had an acidic $\mathrm{pH}$ of 3-4. Hence, it was necessary to treat waste before being discharged into the aquatic environment because the condition can cause the death of aquatic biota. Waste management can be done by a sedimentation process to achieve an optimal $\mathrm{pH}$. The tofu liquid waste which was deposited for seven days as one of the physical tofu liquid waste treatment.

Currently, adsorption methods had been developed using aquatic plants, known as phytoremediation technology. Phytoremediation was a bioremediation technology that applied plants to decontaminate waste both ex-situ and in-situ in waste contaminated areas. Water hyacinth (Eichornia crassipes) was water weed that had fast regeneration power. Hence, the vegetative pieces that carried by the water flow, would develop into adult water hyacinth. Water hyacinth responded very well when the environment had a high concentration of the nutrient content. Water hyacinth had fiber roots with root caps and root hairs. The function of root hairs was absorbing food substances in the water [4].

The use of water hyacinth in the treatment of the tofu liquid waste was an alternative solution that was efficient and effective. It was considering that not many tofu industries had the installation of waste treatment. The effluent from the processing of tofu liquid waste was expected to be safely discharged into the environment because the content of the pollutant material had been absorbed optimally by water hyacinth. After the waste treatment, the utilization of water hyacinth was as the feed of fish and livestock. Based on the background above, the researcher wanted to conduct research on the improvement of the quality of tofu liquid waste by the sedimentation and phytoremediation of Water Hyacinth (Eichornia crassipes).

\section{MATERIALS AND METHODS}

This research was conducted in January-February 2018. The location of water hyacinth phytoremediation research was in the Department of Biology, FMIPA, State University of Surabaya. The Measurement of $\mathrm{pH}, \mathrm{NH}_{3}, \mathrm{NO}_{2}, \mathrm{NO}_{3}$ levels was carried out in the FKM Nutrition Laboratory of Airlangga University.

Manipulation variables used in the research were $100 \%$ of the tofu liquid waste (control), sedimentation for seven days and phytoremediation after sedimentation. The control variables used in this research were the liquid waste of tofu industry, water hyacinth (Eichornia crassipes) as 
phytoremediator, time of exposure (7 days), biomass of water hyacinth (300 grams), place for planting media (aquarium size 20x30x40 cm), media volume planting (5 liters), acclimatization time ( 7 days) and place of exposure. While the response variable used in this research was the ability of phytoremediation with water hyacinth by sedimentation in improving the levels of $\mathrm{pH}$, ammonia, nitrite and nitrate.

The initial phase was to acclimate water hyacinth for seven days by changing the water every two days. It was done when there was a decrease in water volume due to evaporation process. Sedimentation technique was to separate coarse particles and suspended solids from liquid waste. The measurement of tofu liquid waste parameters included the levels of $\mathrm{pH}, \mathrm{NH}_{3}, \mathrm{NO}_{2}, \mathrm{NO}_{3}$ and the final biomass of water hyacinth. Measured $\mathrm{pH}$ using a $\mathrm{pH}$ pen. Before making the measurement, the calibration was done first.

The average value of $\mathrm{pH}$, ammonia, nitrate and nitrite were analyzed statistically using One-sample Kolmogorov-Smirnov Test to find out that the data were normally distributed, then analyzed using one-way Variant Analysis (ANOVA). Data shows significant value so that Duncan Test can be continued. In addition, the data referred to the quality standards of the tofu liquid waste that had been set East Java Governor Decree 2002.

\section{RESULTS}

Based on the results of the research showed that the $\mathrm{pH}$ level increased after the treatment processed which included sedimentation and phytoremediation. The initial $\mathrm{pH}$ before processing is 4.21 and after processing the $\mathrm{pH}$ rose to 7.37. It was in the class II of the waste quality category. $\mathrm{NH}_{3}$ levels in tofu liquid waste media decreased from 6.41 to 1.83 . After being processed and diffitoremediation, $\mathrm{NH}_{3}$ levels decreased even though it was not safe and entered into the class II of the waste quality standard. It was safe in the class III of the waste quality standard. $\mathrm{NO}_{2}$ levels in the tofu liquid waste medium decreased from 1.94 to 0.61 . The level was already safe and included in the class II of the waste quality standard. The level of $\mathrm{NO}_{3}$ in tofu liquid waste media also decreased from 15.91 to 12.66 , so that it was safe and entered the class II of the waste quality standard (Table I.)

TABLE I. THE VALUE OF PH, NH3, NO2, NH3 OF THE TOFU LIQUID WASTE ON PHYTOREMEDIATION OF HYACINTH (EICHORNIA CRASSIPES).

\begin{tabular}{|c|c|c|c|c|}
\hline Treatment & $\mathbf{p H}$ & $\begin{array}{c}\mathbf{N H}_{3} \\
(\mathbf{p p m})\end{array}$ & $\begin{array}{c}\mathbf{N O}_{2} \\
(\mathbf{p p m})\end{array}$ & $\mathbf{N O}_{\mathbf{3}}(\mathbf{p p m})$ \\
\hline Control & $4,21 \pm 0,34^{\mathrm{a}}$ & $6,41 \pm 0,00^{\mathrm{c}}$ & $1,94 \pm 0,00^{\mathrm{c}}$ & $15,91 \pm 0,00^{\mathrm{c}}$ \\
\hline Sedimentation & $6,86 \pm 0,07^{\mathrm{b}}$ & $4,73 \pm 0,02^{\mathrm{b}}$ & $1,03 \pm 0,01^{\mathrm{b}}$ & $14,02 \pm 0,02^{\mathrm{b}}$ \\
\hline $\begin{array}{c}\text { Sedimentation }+ \\
\text { phytoremediation }\end{array}$ & $7,37 \pm 0,06^{\mathrm{c}}$ & $1,83 \pm 0,01^{\mathrm{a}}$ & $0,61 \pm 0,00^{\mathrm{a}}$ & $12,66 \pm 0,12^{\mathrm{a}}$ \\
\hline $\begin{array}{c}\text { the class II of the } \\
\text { waste quality } \\
\text { standard }\end{array}$ & $6-9$ & 1 & 1 & 20 \\
\hline
\end{tabular}

Note: Numbers that followed by different notations $(a, b, c)$ showed the significant differences value between each other at the 0.05 level according to the Duncan Test.
The biomass measurement of water hyacinth that before and after processing had increased. The average biomass of water hyacinth after processing was 363 grams and the average addition of water hyacinth biomass was 63 grams (Table II.)

TABLE II. THE ADDITION OF WATER HYACINTH BIOMASS AFTER PHYTOREMEDIATION BY PRECIPITATION.

\begin{tabular}{|c|c|c|c|}
\hline Sample & $\begin{array}{l}\text { First Biomass } \\
\quad \text { (gram) }\end{array}$ & $\begin{array}{l}\text { Last Biomass } \\
\text { (gram) }\end{array}$ & $\begin{array}{c}\text { Addition of } \\
\text { Biomass (gram) }\end{array}$ \\
\hline A1 & \multirow{9}{*}{300} & 320 & 20 \\
\hline A2 & & 360 & 60 \\
\hline A3 & & 345 & 45 \\
\hline A4 & & 350 & 50 \\
\hline A5 & & 380 & 80 \\
\hline A6 & & 400 & 100 \\
\hline A7 & & 390 & 90 \\
\hline A8 & & 370 & 70 \\
\hline A9 & & 355 & 55 \\
\hline Average & 300 & 363 & 63 \\
\hline
\end{tabular}

The ability or potential Water Hyacinth (Eichornia crassipes) as a phytoremediator. Procces the change of Water Hyacinth morphology by sedimentation was showed in Table III. The results showed that in days 1, 2, 3, 4 the Water Hyacinth morphology was fresh and the leaves were green. In days 5, 6, 7 the Water Hyacinth morphology was started to shrivel but the leaves were still green. In Table IV. Showed that the Water Hyacinth phytoremediation without sedimentation had a bad quality.

TABLE III. THE MORPHOLOGY OF WATER HYACINTH BY PHYTOREMEDIATION AND SEDIMENTATION.

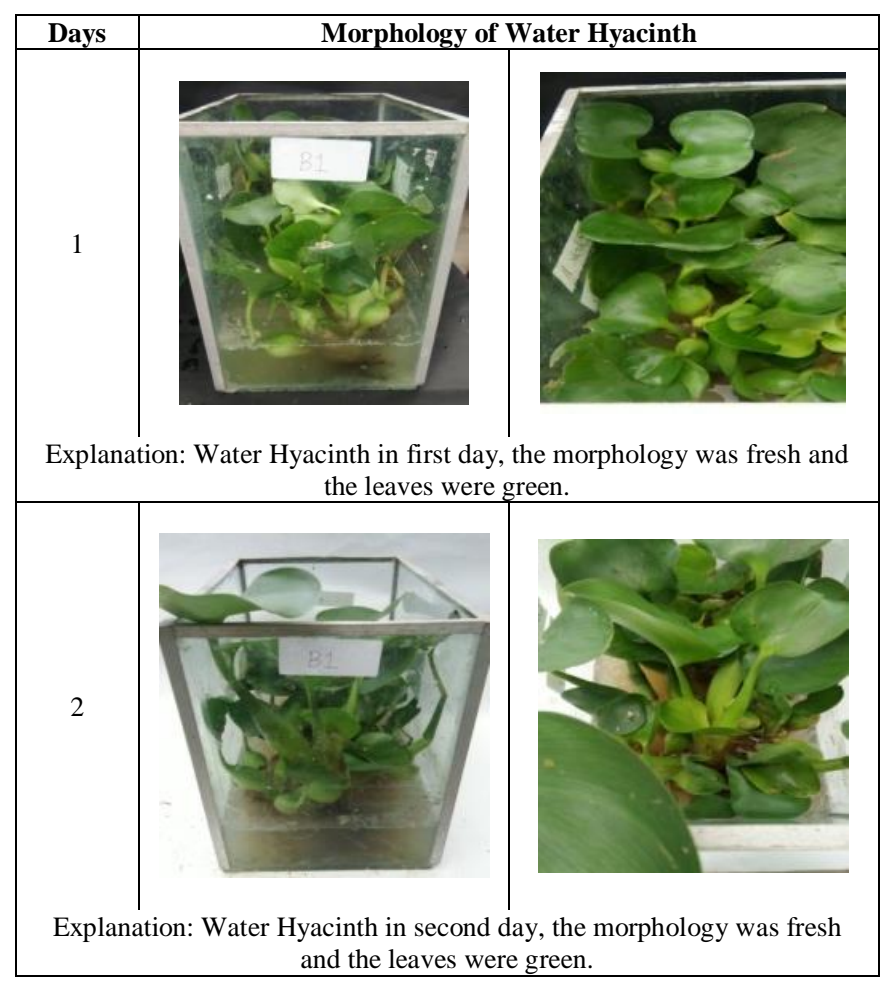




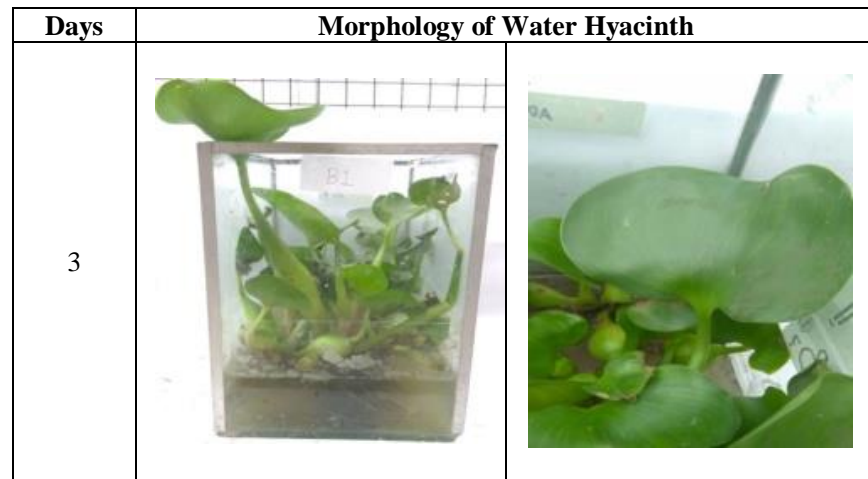

Explanation: Water Hyacinth in third day, the morphology was fresh and the leaves were green.

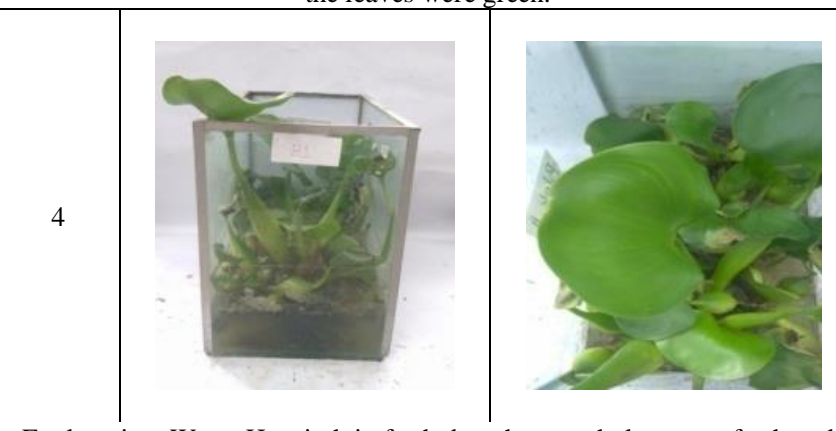

Explanation: Water Hyacinth in forth day, the morphology was fresh and the leaves were green.
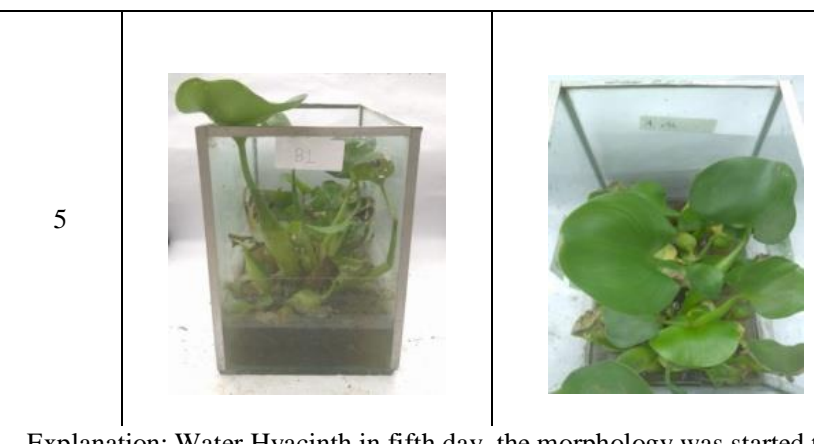

Explanation: Water Hyacinth in fifth day, the morphology was started to shrivel but the leaves were green.
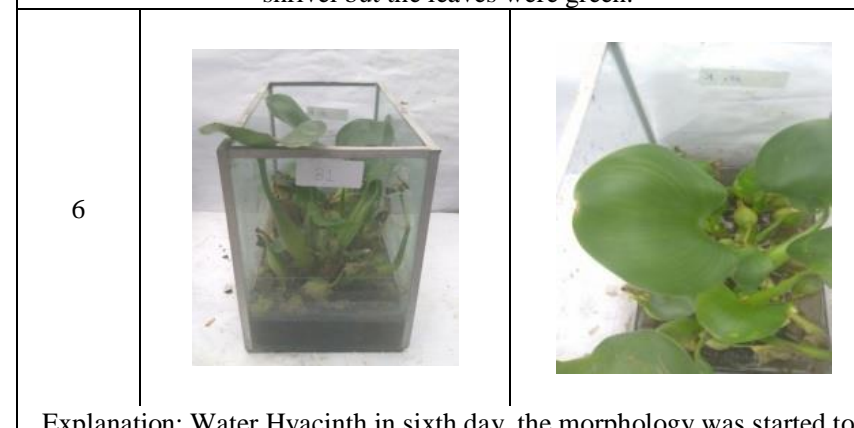

Explanation: Water Hyacinth in sixth day, the morphology was started to shrivel but the leaves were green.

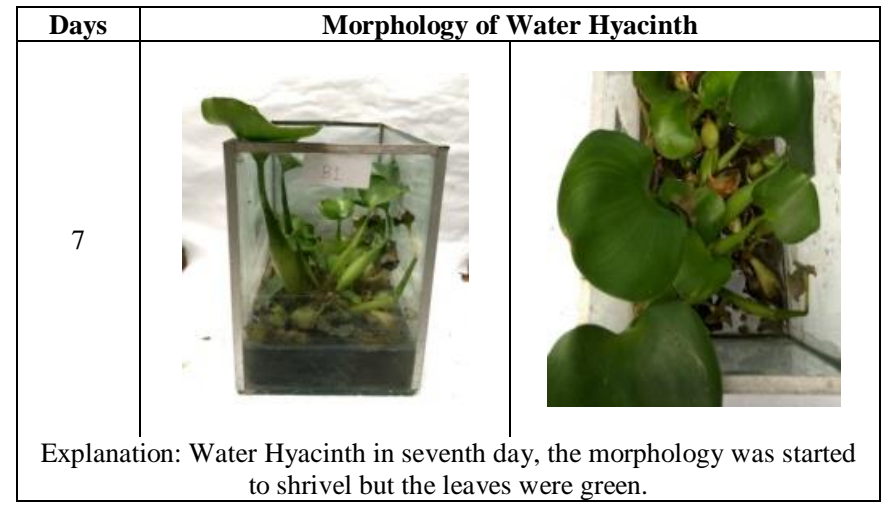

TABLE IV. MORPHOLOGY OF WATER HYACINTH IN PHYTOREMEDIATION WITHOUT SEDIMENTATION.

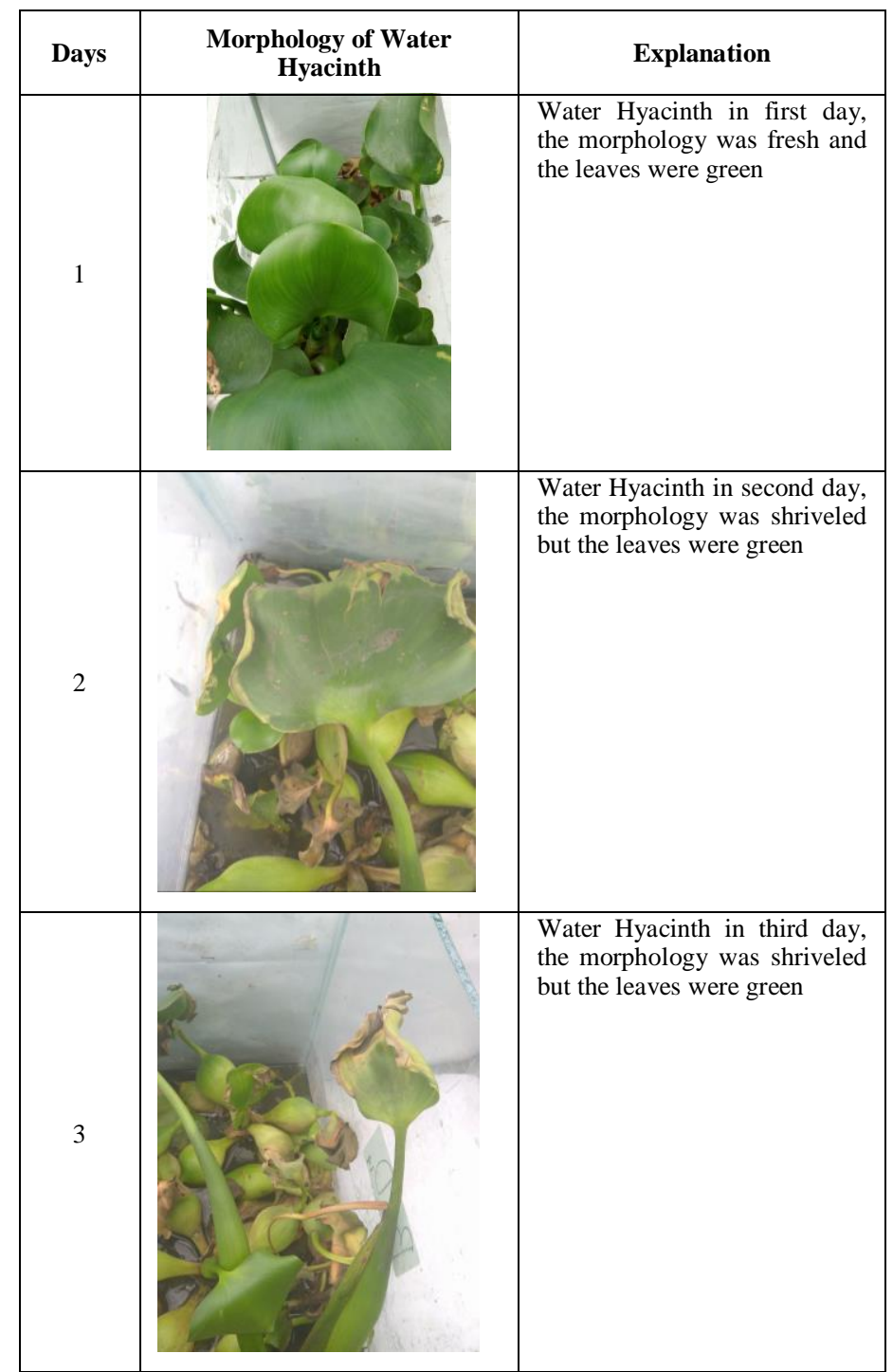




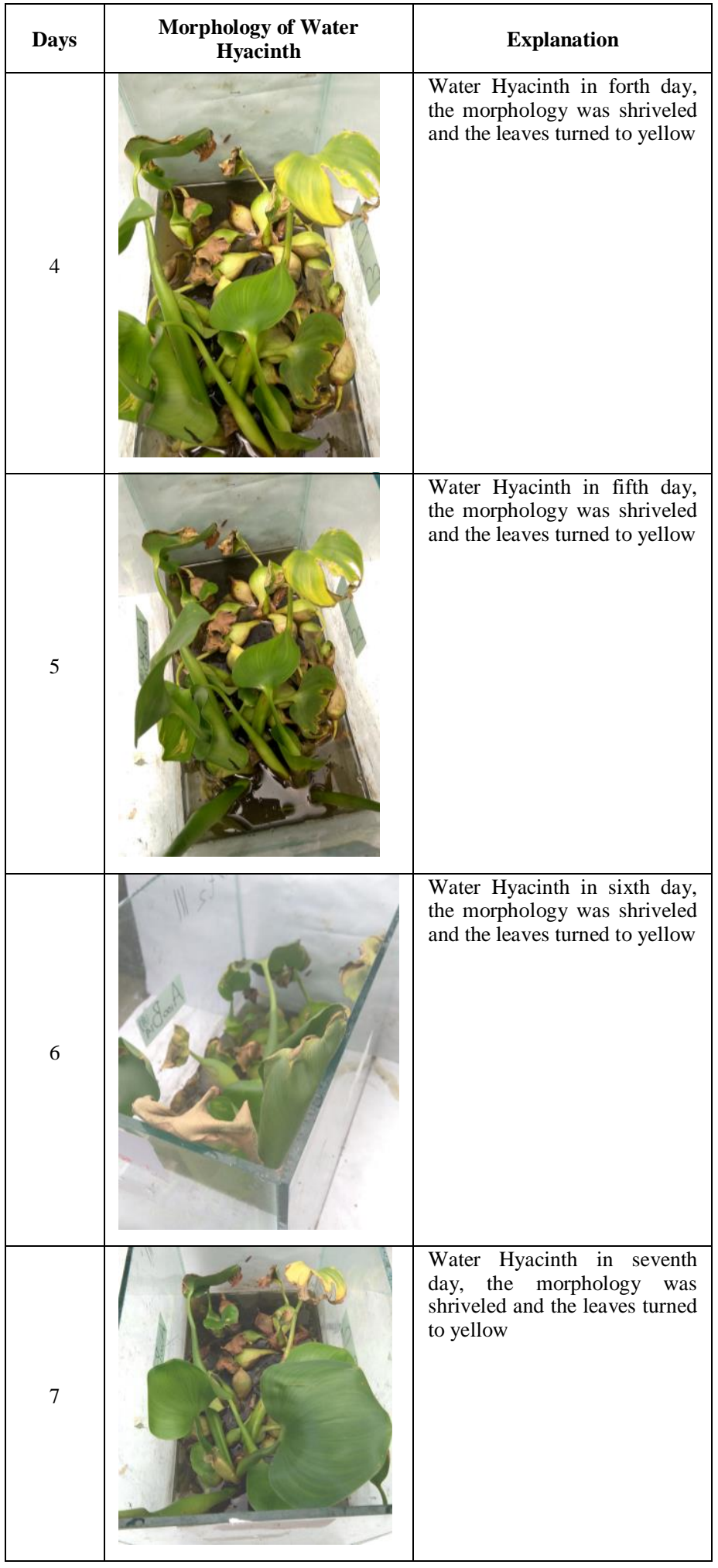

\section{DISCUSSION}

The Tofu liquid waste processing by the sedimentation process can improve the $\mathrm{pH}$ of tofu liquid waste from acid to neutral. It was because the processing by sedimentation can precipitate colloidal particles. Hence, they can be separated from the solution [5]. The initial treatment by the sedimentation process aimed to purify and eliminate toxic substances in the tofu liquid waste with water plants medium such as water hyacinth known as phytoremediation. Phytoremediation was the use of aquatic plants such as water hyacinth which was useful for removing, extracting and detoxifying pollutants from the environment. The tip root of the water hyacinth can absorb organic substances in the tofu liquid waste. Organic substances that were absorbed, were then burned into the stem through the transporting vessels and spread to all parts of the water hyacinth. In this process, the organic substances underwent biological reactions and accumulated in the stem of the plant, then forwarded to the leaves [6].

The $\mathrm{pH}$ of the liquid waste is one of the parameters that affects the quality of liquid waste. $\mathrm{pH}$ testing in this research used a $\mathrm{pH}$ meter. From the results of the research, the $\mathrm{pH}$ of tofu liquid waste was 4.21. This is because a vinegar was added in the process of making tofu. Most aquatic biota are sensitive to changes in $\mathrm{pH}$ and can only tolerate $\mathrm{pH}$ values of 7-8.5. $\mathrm{pH}$ levels of greatly affected biochemical processes in the waters [7]. The increase in $\mathrm{pH}$ is due to organic matter in the tofu liquid waste [8].

The decrease in $\mathrm{NH}_{3}$ values was related to the increase in $\mathrm{pH}$. An increase in $\mathrm{pH}$ will be followed by a decrease in solubility of compounds that were toxic in wastes such as $\mathrm{NH}_{3}$. At $\mathrm{pH} \mathrm{7,} \mathrm{the} \mathrm{decrease} \mathrm{in} \mathrm{ammonia} \mathrm{levels} \mathrm{reached}$ optimum. In addition to the process of absorbing water hyacinth, the process of reducing ammonia levels was also assisted by the decomposition of organic matter by microorganisms. This causes the organic matter dissolved in the tofu liquid waste to decrease [9]. The results showed that the phytoremediation of water hyacinth by sedimentation was able to make ammonia levels in liquid waste down. This was because ammonium can be caused by $\mathrm{N}$ compounds used by plants and microorganisms for new cell biosynthesis. Microorganisms can use nitrogen for microbial cell synthesis, change nitrogen and reduce nitrogen content in the environment.

The decrease of $\mathrm{NO}_{2}$ value was caused the water hyacinth plant can cooperate with microorganisms in the media (soil, coral, and water) and change contaminant substances (pollutants / pollutants) to be less toxic. Organic matter in the tofu liquid waste was degraded by an aerobic oxidation process and will produce more stable compounds. Microorganisms in tofu liquid waste that will oxidize organic matter. Decomposition of organic matter was carried out by two stages; namely organic matter will be broken down into inorganic materials. Inorganic material that was unstable then underwent oxidation into a stable inorganic material. For example, ammonia compounds underwent oxidation to nitrite [10].

The $\mathrm{NO}_{3}$ content decreases due to the rapid growth of water hyacinth. It affected to the absorption of nutrients such as nitrates because it can reduce the concentration of contaminants in aquatic waste [11]. In tofu liquid waste, there 
were generally $\mathrm{N}$ compounds in the form of $\mathrm{N}$-organic namely $\mathrm{N}$-ammonia $\left(\mathrm{N}-\mathrm{NH}_{3}\right), \mathrm{N}$-nitrite $\left(\mathrm{N}-\mathrm{NO}_{2}\right)$ and $\mathrm{N}$-nitrate $(\mathrm{N}$ $\left.\mathrm{NO}_{3}\right)$. Ammonia $\left(\mathrm{NH}_{3}\right)$ and nitrite $\left(\mathrm{NO}_{2}\right)$ compounds will be changed first by the process of nitrification into the form of nitrate compounds and then can be absorbed by water hyacinth. The water hyacinth can absorb directly nitrate compounds $\left(\mathrm{NO}_{3}\right)$ which function to meet nutritional needed in the growth of water hyacinth.

Biomass in water hyacinth (Eichornia crassipes) had increased. The increase in water hyacinth biomass was thought to be due to the condition of the waste media that had a $\mathrm{pH}$ of 7. The roots of water hyacinth were able to absorb the organic material which contained $\mathrm{N}$ compounds and stored them into the water hyacinth vascular tissue. it was for metabolic processes and was used to multiply cells. The tofu liquid waste contained a lot of organic material. Hence, it was used as a nutrient needed for the growth of aquatic plants such as water hyacinth [12]. The rapid growth of water hyacinth showed that water hyacinth had an extraordinary ability to absorb nutrients and other substances. Water hyacinth can grow twice as fast in appropriate environmental conditions such as pH 7 [13]. Water hyacinth also underwent an increase in biomass allegedly. it was caused the tofu liquid waste used in research contained nutrients needed for the growth of water hyacinth such as elements $\mathrm{N}$ and $\mathrm{P}[14]$.

\section{CONCLUSION}

The results of this research showed that the phytoremediation of water hyacinth by sedimentation process was able to improve $\mathrm{pH}$ from 4.21 to 7.37 ; reduce $\mathrm{NH}_{3}$ levels from 6.41 to 1.83 ; reduce $\mathrm{NO}_{2}$ levels from 1.94 to 0.61 ; reduce $\mathrm{NO}_{3}$ levels from 15.91 to 12.66 ; and increase the biomass of water hyacinth.

\section{REFERENCES}

[1] R.D. Ratnani, "Kecepatan Penyerapan Zat Organik pada Limbah Cair Industri Tahu dengan Lumpur Aktif," Momentum, vol. 7, pp. 18-24, 2011.

[2] A. Artiyani, "Penurunan Kadar N-Total dan P total pada limbah Cair Tahu dengan Metode Fitoremediasi Aliran Batch dan Kontinyu Menggunakan Tanaman Hydilla Verticillata," J. Spektra, vol. 18, pp. 911, 2011.

[3] R. Suganda, E. Sutrisno, I.R. Wardana, "Penurunan Konsentrasi Amonia, Nitrat, Nitrit dan COD dalam Limbah Cair Tahu dengan Menggunakan Biofilm-Kolam (Pond) Media Pipa PVC Sarang Tawon dan Tempurung Kelapa Disertai Penambahan Ecotru," J. Teknik Lingkung., vol. 3, pp. 1-8, 2014.

[4] S. Lidiawati and Tusani, Penurunan Konsentrasi Warna Limbah Tekstil Menggunakan Tanaman Air, Surabaya: Pusat Studi Lingkungan Ubaya, 2009.

[5] MetCalf dan Eddy, Wastewater Engineering: Treatment. Disposal and Reuse, New York: McGraw Hill Book Co, 2003.

[6] H.Y. Sriyana, "Kemampuan Eceng gondok dalam Menurunkan Kadar $\mathrm{Pb}$ (II) dan Cr (VI) Pada Limbah dengan Sistem Air Mengalir dan Sistem Air Menggenang," Master Tesis, Yogyakarta: Universitas Gajah Mada, unpublished, 2006.

[7] K. Ria, "Proses Fitoremediasi Limbah Cair Tahu Untuk Menurunkan COD dan TSS dengan Memanfaatkan Kiambang," J. Teknik Kimia, vol 6, pp. 31-36, 2015.

[8] C. Jenny and Guido, "Fitoremediasi logam timbale $\mathrm{Pb}$ menggunakan tanaman melati air (Echinodorus palaefolius) pada limbah industri peleburan tembaga dan kuningan," J. Teknik Lingkung., vol 3, pp. 733744, 2015.

[9] Irmanto and Suyata, "Penurunan Kadar Amonia, Nitrit dan Nitrat Limbah Cair Industri Tahu Menggunakan Arang Aktif Dari Ampas Kopi,” J. Kimia, vol 4, pp. 105-114, 2009.

[10] H. Effendi, Telaah Kualitas Air, Yogyakarta: Kanisius, 2003.

[11] T. Juhaeti, F. Syarif, and N. Hidayati, "Inventarisasi tumbuhan potencial untuk fitoremediasi lahan dan air terdegradasi penambangan emas," Biodiversitas, vol 6, pp. 31-33, 2005.

[12] S.D.T.S.E. Sugiarti, Kandungan Bahan Organik Di Situ Perikanan, Bogor: Institut Pertanian Bogor, 2002.

[13] J.A. Coetzee, M.P. Phill, M.H. Julien, T.D. Center, and H.A. Cordo, "Eichhornia crassipes (Mart.) Solm-Laub. (Pontederiaceae)" in Biological Control of Tropical Weeds using Arthropods, R. Muniappan, G.V.P. Reddy, and A. Raman, Eds. Cambridge: Cambridge University Press, 2009, pp. 181-208.

H.D. Rahmaningsih, "Kajian Penggunaan Eceng gondok (Eichhornia crassipes) Pada Penurunan Senyawa Nitrogen Efluen Pengolahan Limbah Cair PT. Capsugel Indonesia," Undergraduate Thesis, Bogor: Institut Pertanian Bogor, unpublished, 2006. 